UDC 323.1:929 Pribićević S.

Дарко Гавриловић

Оригиналан научни рад

Универзитет у Новом Саду

Природно-математички факултет

примљено: 1. јул 2012

gavrilovicdarko@yahoo.com

прихваћено: 1. октобар 2012

\title{
ВРЕМЕ ПОЛИТИЧКОГ САЗРЕВАЫА СВЕТОЗАРА ПРИБИЋЕВИЋА 1875-1905
}

Сажетак: У раду ће аутор да прикаже политичко стасавање Светозара Прибићевића у периоду од краја 19.века па до стварања Хрватско-српске коалиције. Настојати ће да пружи преглед и анализу његових основних политичких ставова у вези са српским питањем у Хрватској као и са питањем хрватско-српске сарадње.

Кључне речи: Светозар Прибићевић, Срби, Хрватска, политика, сарадња, јединство

Доба сазревање 1875-1903

У новијој српској историји Светозар Прибићевић је без сумње био крупна историјска личност, а самим тим и један од најзначајнијих и најутицајнијих политичара на хрватској и југословенској политичкој сцени у првим десетлећима 20. века. Од 1905. године до 1918. године он је био вођа Српске самосталне странке у Хрватској и један од оснивача Хрватско-српске коалиције, да би, са стварањем Краљевине СХC 1918. године, његова личност постала нераскидиво везана за страначке организације којима је од тада био на челу (Демократска странка, Самостална демократска странка).

Аустро-угарском нагодбом од јуна 1867. године, Хабзбуршко царство је претворено у двојну монархију. Суштина нагодбе се састојала у томе да се изједначе две државе које су се изградиле око Аустрије, односно око Угарске, са циљем да се оствари хегемонија Немаца и Мађара над словенским народима у Монархији. По тој подели, Хрватска и Славонија су припале под сферу утицаја Угарске, док су Далмација и Истра остале под Аустријом. На основу ове нагодбе, склопљена је Хрватско-угарска нагодба 1868. године по чијим је одредбама створена државна заједница у којој је Хрватска добила своју самосталност, али је Угарска упркос повољним одредбама нагодбе по Хрватску, успела да обезбеди своју хегемонију у највишим органима власти, у пословима који су се сматрали заједниким, као и у финансијама и привреди. До појачаног притиска Угарске на 
Хрватску дошло је упоредо са појачаном мађаризацијом у Угарској након спајања Деакове странке са радикалима Калмана Тисе, као и његовим доласком на власт 1875. године. Ова влада је, корак по корак, уклањала поједина обележја државнополитичке индивидуалности Хрватске у заједничким пословима и посредним путем проширивала своју ингеренцију на аутономне послове. Упоредо са политиком мађаризације дешавао се и нагли пораст порезних оптерећења који су најтеже погађали широке народне слојеве, а посебно сељаштво.

Исте године, у Босни и Херцеговини избио је устанак хришћана против турских власти. Већина устаника били су Срби, али значајан допринос устанку дали су и Хрвати, међу којима су се нарочито истицали: Иван Мусић, Иван Беговић и Боно Дрежњак. Устанак је наишао на велики одјек у суседним земљама. Тадашњи хрватски бан Иван Мажуранић, као и готово целокупна хрватска јавност, са симпатијама су пратили ток устанка, али пошто је добронамерно држање Беча убрзо заменила суздржљивост која је постајала све већом уколико се јаче осећао утицај Црне Горе и Србије на устанике, то је и однос бана према устаницима већ на јесен 1875. године постао суздржан.

Наиме, треба имати на уму да је Аустро-Угарска благонаклоно гледала на устанак само због сопствених апетита према Босни и Херцеговини, која би јој, у случају присаједињења омогућила продор на Исток, али и вратила пољуљани углед велике силе који је изгубила са тешким поразима у ратовима и губицима територија од стране Пруске и Италије.

У исто време јавиле су се претензије Срба, односно Хрвата на Босну и Херцеговину, и тако погоршале ионако лоше политичке односе између та два народа, што су владајући кругови у Бечу и Пешти знали вешто да искористе, па су тај антагонизам потпиривали са своје стране, на разне начине, што су јаче могли. Ипак, све те тешкоће и спорна питања нису успели да помуте симпатије српског и хрватског народа према устаницима, јер дуж границе са Аустро-Угарском оснивани су одбори, који су помагали устанике свиме у чему су ови оскудевали.

Један од оних који је дао свој допринос у тим акцијама био је отац Светозара Прибићевића, Милутин Прибићевић. Понесен политичком активношћу Светозара Милетића, као и акцијама његове Српске народне слободоумне странке, која је своју политичку активност од 1869. до 1873. године по питању развојачења Војне границе подесила према тежњама српског народа у њој, у смислу добијања засебне управе и посебне скупштине или сабора, он је очаран харизматичном личношћу овог истакнутог српског политичара, 26. октобра 1875. године, свом другорођеном сину дао име Светозар.

О томе да је српска свест била развијена у њиховој родној кући, писао је Адам Прибићевић, Светозаров брат. То расположење није престало ни после пораза устаника из 1878. године, јер је Светозар у другом разреду реалне гимназије покушао да пребегне у Србију. О тој његовој типично пубертетској авантури брат Адам је забележио: “Што је он пошао у Србију, сасвим је природно. Отац и мати отхрањивали су нас у дубокој оданости према српској народној идеји и потпуно некритичкој љубави према Црној Гори, Србији и Русији. Светозар је мислио да ће га у Србији посадити у крило и посипати шећерлемама. Али је чудно да се дете од 
дванаест година усудило само, без игде ичега кренути толико далеко и веровало да ће успети. Овај нагон за далеким циљевима остаће његова особина до краја живота. Увек је он тако, за вољу далеких циљева, био слеп за све споредно, у што је спадала удобност и његова и његових најближих.”Пемда му покушај бега није успео, он га није спречио да поново покуша да побегне четири године касније, када је са успехом стигао у Београд. Оставши тамо без средстава за живот, био је присиљен да се убрзо врати у Хрватску и да заврши гимназију, код једног рођака, у Карловцу 1894. године, као одличан ђак. ${ }^{2}$

Универзитетске студије из математичко-физичке групе завршио је на Универзитету у Загребу. Док је био студент, политичке борбе између Срба и Хрвата у Хрватској биле су веома жестоке, а кулминирале су противсрпским демонстрацијама у Загребу 14. и 15. октобра 1895. године, у време посете Фрање Јосифа главном граду Хрватске. Разлога за политичке борбе било је много, али корен узајамном непријатељском држању био је један, а то је чињеница да су хрватске странке своју идеју државног права заснивале на средњовековном мађарском државном праву када је у питању било признавање српског народа у Хрватској. Другим речима, по том праву, Мађари су били једини политички народ у Мађарској, па је сходно томе и већи део хрватских политичара сматрао Хрвате за једини политички народ у Хрватској. Наравно, да је из таквог става произашао читав низ проблема у српско-хрватским односима, који су се, уз повремене добре односе и покушаје на сарадњу, задржали све до данашњих дана. У то време, најјаче опозиционе странке у Хрватској, нису признавале ни српски народ ни српско име. Са једнаком жестином, та опозиција је нападала како Србе који су били блиски Куену, тако и српску опозицију која је, слично хрватској опозицији бранила аутономију Хрватске и Славоније коју су угрожавали Мађари и Куен. Прогоњени су српски учитељи, а затваране српске школе. Српски политичари, нарочито нотабилитети и присталице Народне странке, одговарали су на те нападе тако што су подржавали бана Куена Хедерварија, који је учвршћивао мађарски утицај у Хрватској, и у исто време свим силама радио на разбијању јединства српског и хрватског народа.

Нашавши се у времену жестоких националних сукоба од којих је једину корист имао трећи, односно, мађарски владајући кругови, Прибићевић је одлично увидео сву узалудност међусобних трвења. О хрватским и српским политичарима у то време он је имао мало лепих речи, осим за Франка Поточњака, о којем је, присећајући се својих студентских дана, много година касније, писао: „Он је један од ријетких хрватских политичара, којима Срби могу вјеровати без резерве. Изјављујући се у саборској периоди од 1897. до 1901. за равноправност српског народа са хрватским ... остао је на том темељу непромјењен и даље.“3 Поточњак је за Прибићевића био „пут до сређених односа у читавом нашем народном животу, у

\footnotetext{
${ }^{1}$ Подаци из Поговора др. Богдана Кризмана у књизи Светозара Прибићевића, Диктатура краља Александра, Загреб 1990, 276.

${ }^{2}$ Владимир Ћоровић, Портрети из новије српске историје, Београд 1990, 224.

${ }^{3}$ Нови Србобран, 91 / 29.4 (12.5) 1905, 1.
} 
чем лежи једино јамство за успјех народне политике, и српске и хрватске.“4 $3 а$ време студија Прибићевић је оцењивао и рад Јосипа Јураја Штросмајера, којег је с једне стране називао „великим сином хрватског народа, а највећим му сином 19. вијека“, признавајући при том да „слава његова остаје ипак трајна и непролазна, јер се не заборавља његова преписка са кнезом Михајлом“, али му је, у исто време и замерао, да је „... имао својих мана и погријешака ... због посланице, којом је позивао српски народ у своју цркву ... и због његовог мирења и пактирања са покојним Старчевићем, као и његовог учешћа на католичком конгресу у Загребу.“5

Суочен са суморном политичком стварношћу у којој су се странке оба народа исцрпљивале у међусобној борби, Прибићевић је са још неколицином својих другова, одлучио да крене другим путем, па се тако већ у фебруару 1896. године придружио српској и хрватској омладини која је искористила прославу седамдесетогодишњице Светозара Милетића да би се међусобно зближили и нашли заједничку основу за даљу сарадњу. Пошто је од раног детињства Прибићевић растао у породици где се Милетићево име изговарало са великим поштовањем, за њега је ова прослава била прави доказ будућег заједничког рада о чему је писао и много година касније у свом делу „Диктатура краља Александра“.

Политичко искуство у Хрватској до 1897. године показало је да притисак извана неће моћи да се уклони без заједничке борбе Хрвата и Срба и без демократизације јавног живота. Хрватска се и даље налазила под жестоким притиском режима бана Куена Хедерварија, који је ишао за тим да Хрватску покори искључивим интересима угарске владе, при том се служећи: онемогућавањем противдуалистичких снага у њиховом деловању, потпиривањем сукоба између хрватске и српске буржоазије и још бољим оспособљавањем свог чиновничког апарата за потискивање и најмање појаве националног отпора.

Због тога, Прибићевић је са својим колегама, студентима загребачког универзитета, усмерио сву енергију на окупљање хрватске и српске омладине, покушавајући је придобити идејом народног јединства. Ова идеја, постала је срж његове идеологије, и таквом ће остати све до шестојануарске диктатуре. Сличним путем, 1897. године, кренуо је и један део хрватске омладине понесене Масариковим предавањима у Прагу. Тамо, они су покренули лист „Хрватска Мисао“, у којем су наглашавали да су Срби и Хрвати један народ. Предвођени Стјепаном Радићем, прашки омладинци су анализирали назадовање политичког живота у земљи и при том долазили увек до јединственог закључка да се одбрана од туђинске хегемоније може спровести само српско-хрватском сарадњом. Млада интелигенција је почела да осуђује дотадашњу негативну политику хрватских грађанских странака и тражила је сопствени пут. Следеће године „Хрватска мисао“ је због жестоких критика упућених влади, хрватском друштву и опозицији, престала да постоји, а покренут је лист „Ново доба“, као орган српских, хрватских и слоовеначких омладинаца. Пошто је и тај лист ускоро забрањен у Хрватској, покренут је у Бечу 1899. године, заједничким снагама Светозара Прибићевића и

\footnotetext{
${ }^{4}$ Исто.

${ }^{5}$ Исто, 67 / 28.3 (10.4) 1905, 1-2.
} 
Стјепана Радића, лист „Глас“, који слично његовим претходницима такође није био дугог века. У том листу, Радић се солидарисао са Прибићевићевим смером и начином писања који су били на линији народног јединства Срба и Хрвата, али већ тада, за разлику од Прибићевића, он је био за „такво југославенско државно и народно јединство, које ће половицу нашега народа ујединити у Хабзбуршкој монархији, у Краљевину Хрватску, а другу половицу изван Монархије у балкански савез и то тако, да Хабзбуршка монархија и балкански савез буду најбољи пријатељи.“6 За разлику од Радића, који је био Хрват, Прибићевић, као Србин, имао је сасвим другачије погледе по питању уједињења. Наиме, поприличан број хрватских односно српских политичара националне орјентације који су развејавали идеју националног уједињења на првом месту су посматрали сопствене националне интересе. Сходно томе, део хрватских политичара међу којима је био Стјепан Радић видели су национално уједињење тако да се оно треба извршити око Хрватске, а без Србије, јер би то омогућило стварање већине хрватског народа, а српски политичари међу којима је био и Прибићевић гледали су како да се уједињење оствари заједно са Србијом да би на тај начин постигли што више од српских националних интереса, а који су ишли за окупљањем Срба у једној заједничкој држави. Због тога, Прибићевић је сматрао да ће „Срби и Хрвати полагати једнако право на сваки дио наше народне заједнице, звао се тај дио Хрватска и Славонија, Далмација, Истра, Међимурје, Бачка, Банат, Србија, Босна и Херцеговина, Црна Гора, Стара Србија, Мачедонија.“7 ${ }^{7}$ Те разлике у мишљењу, неколико година касније, постале су још дубљима, пошто је Радић из корена изменио свој однос према Србима након што је Хрватско-српска коалиција повела опортуну политику, описујући године заједничке борбе и мисао да су Срби и Хрвати један народ, као „безумље“. Тако су се два пријатеља и истомишљеника након Ријечке резолуције нашла на супротним странама: Радић са франковцима, а Прибићевић у кругу коалиционаша.

Идеје које је Прибићевић за време студија износио у наведеним часописима, он је, у ствари, објединио већ на самом почетку свог политичког рада, у чланку под насловом „Мисао водиља Срба и Хрвата“, који је изашао 1897. године у „Народној Мисли““ темељне политичке оријентације и програм његове политичке активности све до пред сам крај живота. Након општих разматрања, на почетку свог чланка, о појави идеја, од којих је национална идеја та која покреће модерно човечанство, он је изнео главну мисао, а то је да „Срби и Хрвати нису два различита, него су они дјелови једнога, истога, народа.“9 $И$ да већ због тога, као и због заједничке прошлости, та два народа „Срби и Хрвати морају се у Троједници здружити у једну народну странку, која ће подржавати културне везе с осталим дијеловима нашега

\footnotetext{
${ }^{6}$ Србобран, 151/ 9.(22) 7. 1914, 2.

${ }^{7}$ Светозар Прибићевић, Мисао водиља Срба и Хрвата, Београд, 1940, 28.

${ }^{8}$ Алманах „Народна мисао“ био је лист „уједињене хрватске и српске академске омладине“, а у њему су објављивали своје радове: Јован Бањанин, Милан Костић, Иван Лорковић, Лав Мацура, Душан Манђер и Светозар Прибићевић.

${ }^{9}$ Светозар Прибићевић, Мисао водиља Срба и Хрвата, 9.
} 
народа захтјевати самосталност Троједнице на основу начела народне суверености.“10 Да би тај закључак потврдио агрументима, он је написао да имена Србин и Хрват су у ствари „један исти појам“; а да је у свом политичком раду до 1905.године радио на стварању услова за успостављање тесних веза између хрватских и српских политичких странака доказ је био оснивање Хрватско-српске коалиције. То су, према његовом мишљењу, народна имена за обележавање једног народа. Верске разлике он није сматрао довољним доказом да су Срби и Хрвати два различита народа, а питање језика у потпуности је искључио из расправе, јер је сматрао да они говоре исти језик. Прибићевић је у чланку реално проценио тежак положај Хрватске као и стварну потчињеност свих њених становника, али, из те процене, он је извео нереалан закључак, а то је - мисао о јединственом народу. Та идеја националног унитаризам постала је основом његове целокупне политичке активности како у Аустро-Угарској, тако и у новоствореној југословенској држави, с тим што је од 1918. године он у оквире свог југословенства укључио и Словенце.

Ушавши у политички живот, Прибићевић је одбацио државно-правне аргументе и историјске чиниоце, не признавајући никакве разлике међу југословенским народима, а потребу тесне сарадње појачао је до националног интегрализма, јер је сматрао да се тенденцији претварања „земаља круне св. Стјепана“ у јединствену мађарску државу може супротставити само на тај начин. Већина омладинаца била је његовог мишљења, али је заједнички став био тај, да се без промене политичког курса тадашњих странака, не може остварити преко потребно јединство. Због тога, на конференцији у Максимиру 1898. године, „омладинци (мисли на круг Напредне омладине, оп. Д.Г.) су се споразумјели да по властитим увјерењима приступе основаним српским и хрватским странкама, да би у њима дјеловали у том смислу.“11 Тако је Прибићевић после завршених студија и годину дана службе на месту професора, одлучио да се посвети новинарском позиву и да приступи Српској самосталној странци, ${ }^{12}$ на чијем се челу, у то време, налазио др. Богдан Медаковић. О тој одлуци, Прибићевић је много година касније писао да је „ушао у ову странку са српском омладином и реформисао њен програм. Нови је програм пристао уз гледиште о народном јединству Срба и Хрвата и захтјевао је корјените демократске реформе.“13 Неоспорно је да је Прибићевић у томе за кратко време успео, јер премда је припаднике те странке у свом „Гласу“ оштро осуђивао као нагодбењачке опортунисте и као групацију која није озбиљан политички чинилац, он је у периоду од 1902. до 1905. године постао један од најугледнијих српских политичара млађе генерације у Хрватској. ${ }^{14}$ У том периоду, он је у странци брзо напредовао, па је тако средином децембра 1902. године преузео функцију уредника страначког листа „Нови Србобран“, да би ускоро после

\footnotetext{
${ }^{10}$ Исто, 30.

${ }^{11}$ Светозар Прибићевић, Диктатура краља Александра, Загреб 1990, 15.

${ }^{12}$ Српска самостална странка основана је 1881. године, а програм јој је био: борба за очување српске посебности у Хрватској и за једнакост Срба са Хрватима, као и поштовање црквено-школске аутономије, уз истицање потребе ревизије Хрватско-угарске нагодбе.

${ }^{13}$ Светозар Прибићевић, Диктатура краља Александра, 13.

${ }^{14}$ Глас, 2 / 1899, 3.
} 
тога преузео и место генералног секретара, након чега је почео да даје нове импулсе у политичком иступању своје странке.

Од јачања странке до интензивирања хрватско-српске сарадње

Јужнословенско питање нарочито се заоштрило 1903. године. Тада се у Хрватској буди широки народни покрет који је у почетку био усмерен против мађарске хегемоније, а потом и против хабзбуршке власти. Овом покрету је главни замах дала нова напредна генерација, која је продрмала поново уједињену опозицију хрватских опозиционих странака из њене пасивности и учинила је након две године политички активном у новој форми, „Хрватско-српској коалицији“.Ти догађаји су довели до тога да је Куен Хедервари отишао са места бана. Исте године дошло је до значајних промена у Србији. Дошло је до смене династија, тако да уместо Александра Обреновића, којег су завереници мучки убили, на престо је дошао Петар Карађорђевић. Ова промена у Србији задала је озбиљан ударац аустро-угарској спољној политици, која је у династији Обреновића имала савезника, али и мирног, послушног сарадника, за разлику од Карађорђевића, који су се везали за Русију и самим тим се испречили немачким и аустријским плановима за продор на исток. Све то је подстицало политику новог курса, чији творци су тежили да се споразумеју са свим противницима немачког „Продора на Исток“. Та се политика заснивала на сарадњи Хрвата и Срба, а као крајњи, далеки циљ, постављала је стварање југословенске државе. Непосредни програм новог курса био је рушење лажног уставног стања и увођење грађанских демократских слобода, с тим да је требало порадити на томе да се Далмација уједини са Хрватском. Наравно, да је такав план „освежених“ хрватских и српских странака у Хрватској поставио аустријске и мађарске владајуће кругове за њихове највеће непријатеље. Ипак, до уједињења већег дела опозиције у Хрватској, требало причекати још две године.

До тада, Прибићевић је заједно са страначким друговима настојао да оснажи своју странку, да повећа број извршних одбора, непрестано, при том, сазивајући на десетине скупштина и састанака који су имали задатак да је омасове у српском народу широм Хрватске. У то време, он се, у складу са политичким српским националним интересима, жестоко супротстављао „католичкој пропаганди“ која је „почела у Босни и Херцеговини одмах, како је Аустро-Угарска окупирала ове земље ... најбољи доказ за то је официјелни орган католичке цркве, који ... излази у Линцу: Овај је прошле године писао: „Аустрија је извела у Босни знатно цивилизаторско дјело ... По садашњем стању ствари окупиране су покрајине праве мисионарске земље! ... Од окупације број католика се повећао за 70000 у окупираним покрајинама, а у самом Сарајеву нарастао је број њихов од 300 на 12000 душа ... Допис завршујем изјавом, да ни православни ни муслимани не би имали ништа против католика, кад они својом пропагандом не би вријеђали слободу рада осталих вјероисповјести.“ 15 Прибићевић је, осим верске

\footnotetext{
${ }^{15}$ Нови Србобран, 198 / 3. (16) 9. 1903, 2.
} 
равноправности, тражио за Србе „да се узакони равноправност српског имена с хрватским, ... ћирилице с латиницом, и слободно и неограничено употребљавање српске народне заставе.“"16 У то време велике притиске трпела је и српска штампа у Хрватској. Његов лист „Нови Србобран“ често је био забрањиван, а Прибићевић није устајао само у одбрану слободе штампе већ је исправно процењивао тврдећи да „оно што је српско не воли се у овој земљи, а ми се морамо борити да се српство поштује...Слобода штампе и састајања су два средства којима се може много учинити за обрану народних права и олакшање народних терета. Али код нас новине не смију слободно писати и људи се не смију слободно састајати.“17 Исте године, премда је радио на приближавању са хрватском опозицијом која се ујединила у Хрватску странку права, истичући како је његова странка „ставила у свој програм све оно што је саржано у 3. точки резолуције хрватске странке права“ (оп. аутора - 3. тачка садржи: реформу изборног реда, финансијску самосталност Хрватске, заштиту сељачког поседа, обртничког и радничког сталежа, личну слободу, слободу штампе и удруживања), он ју је и нападао тврдећи да су у њу „ушли елементи, који се у многим питањима по својим начелима дијаметрално разликују. Чини се да сваки од тих елемената ишчекује нешто друго од те нове странке ... Главни саставни елемент ове странке су обзораши и један дио праваша. Пошто држимо да је апсолутно немогуће да се људи овако на пречац одрекну свих својих традиција, не можемо никако вјеровати да ће се ови људи одрећи свог држања према српском народу.“18 И ту је био у праву, јер праваши су били управо они који су Хрватску странку права настојали да учине суздржаном по питању признања Срба у Хрватској и који су успоравали њен рад када је тражено да се што пре приступи слози између Срба и Хрвата. Треба напоменути да је „Нови Србобран“ током 1903. и 1904. године изражавао истовремено наду и сумњу у новостворену Хрватску странку права. Он је поздравио њено демократско определење и одвајање од Франкове струје, али је истовремено показао незадовољство због тога што је ХСП прихватила програм из 1894. године и тиме поново дошла до негације Српства, што је створило препреку за сарадњу против „Дранга“. 19

Међутим, Прибићевић и његови политички другови окупљени око „Новог Србобрана“ нису само испољавали незадовољство према новоствореној ХСП, већ и против Франка и његове Чисте странке права. Треба имати на уму да је деведесетих година 19. века Старчевићеву странку права захватио процес који је њен антидуалистички програм прво претворио у умереноопозициони, да би се коначно, када је Јосип Франк преузео у своје руке лист „Хрватска“, трансормисао у продинастички. До расцепа у странци је дошло 1896. године када су настале две

\footnotetext{
${ }^{16}$ Говор Светозара Прибићевића на другој скупштини Српске самосталне странке у Пакрацу од 2. (15) 11. 1903, пренео је „Нови Србобран“, бр. 248 / 3. (16) 11. 1903, 2.

${ }^{17}$ Говор С. Прибићевића на Другој скупштини Српске самосталне странке у Пакрацу. Србобран, бр.248, 3(16) 11 1903, 2.

${ }^{18}$ Нови Србобран, 23 / 21.1 (3.2.) 1903, 1.

${ }^{19}$ Ранка Гашић, Србобран гласило Српске самосталне странке у Троједници 1903-1914, магистарски рад, 103.
} 
струје; једна окупљена око листа „Домовина“ и по њему названа домовинаши и друга окупљена око Јосипа Франка и по њему названа франковци. Франкова странка је била у најтешњој вези са великоаустријским круговима, надајући се да ће из сарадње са двором успети да извуче за Хрватску тријалистичко решење, чиме би Хрватске постала трећа равноправна јединица унутар Хабзбуршке монархије. Сарадња франковаца са двором и њихово непризнавање Срба у Хрватској, као и противсрпске демонстрације које су покренули 1902. године били су довољни Прибићевићу и самосталцима да се у свом листу често на негативан начин осврћу на рад Франкових праваша. У тим освртима, о Франку се писало као о човеку без нације и религије, а често су га нападали називајући га „шајлоком који скида фунту меса са живог тела српског народа“ у иначе уобичајеном за „Србобран“ антисемитском маниру. Међутим, највећи разлог за жестоке нападе на Франка био је тај што је он био препрека стварању српско - хрватског фронта против „Дранга“ и што је сарађујући са клерикалцима окупио фронт одан двору. ${ }^{20}$ Односно, Франкова визија хрватских националних интереса била је у дијаметралној супротности са идејом хрватско-српског јединства. Она није укључивала српске националне интересе већ их је превиђала и тражила је решење у сарадњи са бечким владајућим круговима.

Слично Прибићевићу мислио је и Стјепан Радић, који је франковце и један део праваша сматрао сејачима народне мржње и раздора, али је у исто време веровао да је Хрватска странка права, којој је он био секретар још од 1902. године, способна да преузме власт у Хрватској и да успостави слогу између Срба и Хрвата. Радићеве говоре „Нови Србобран“ је тада често преносио на првим страницама, при томе га хвалећи како се „одликује красним мислима, истинским родољубљем и правим схватањем живота и политичке борбе.“ 21

Међутим, Прибићевић те године није нападао само клерикалне кругове и конзервативнији део праваша, он је са несмањеном жестином водио борбу и против Српске народне радикалне странке, која је почела да се организује у Хрватској и Славонији, с намером да сузбију утицај самосталаца, а ојачају свој. И тако док се конзервативним правашима супротстављао због тог што су ови увек на прво место стављали хрватске националне интересе а запостављали српске, дотле је против радикала водио битку која је била везана првенствено за гласове српских бирача. Наиме, радикали су повели одлучну борбу против Српске самосталне странке, видећи у њој јединог противника у придобијању гласачког тела, запостављајући при том борбу против постојећег политичког система, што су самосталци искористили као адут за даље нападе на њих. ${ }^{22}$ Радикали су им узвраћали тврдњама да су „исувше слаби“ да их „преплавише Бранковци, а још више људи, владиновци, клерикалци, због којих не може напред ... а да учини што корисно за народ, за то ће бити неспособна, као што је и данас.““23 Прибићевић је за време тих сукоба у својим

\footnotetext{
${ }^{20}$ Исто, 109-112.

${ }^{21}$ Нови Србобран, 54 / 27.2 (13.3) 1903, 3.

22 Лазар Ракић, Радикална странка у Војводини 1902-1919, Нови Сад 1983, 138-139.

${ }^{23}$ Застава, 25 / 4.2 1903, 3.
} 
текстовима настојао да смири разбукталу страначку борбу упозоравајући „да су Угарски Срби тридесети део становништва ..... Срби су тако мали да се једва виде у овом шаренилу народносном ... па ипак могу да се сложе ... ми не можемо поднети овај луксуз,“ ${ }^{24}$ истичући при том да су у Хабзбуршкој монархији Срби „мали народ ... па је томе нужно да дође до уједињења српских странака да би се осигурао опстанак народа.“ 25 О даљој борби српског народа у Хабзбуршкој монархији за своја права Прибићевић је био мишљења да њено тежиште треба пренети „у Загреб и Пешту, као и да је неопходно одржавање сеоских скупштина ... оснивање народних књижница ... једном рјечју марљив рад у народу.“ ${ }^{26}$ Он је добро осетио када је дошао тренутак да се тежиште политичке борбе Срба са народно - црквеног сабора пребаци на Хрватски сабор, односно да Хрватска постане центар политичког окупљања Срба из Угарске, и на томе је током целе 1904. године радио.

На жалост, почетком 1904. године, политички односи између хрватске и српске опозиције су се и даље споро отопљавали. О томе, он је писао не само у „Новом Србобрану“ већ и у „Политици“. У свом чланку Прибићевић истиче да је Хрватска и Славонија због српско-хрватских несугласица осуђена да води политику „граваминалну, јер Срби и Хрвати везани овим спором, нису подобни ни зато, да основни земаљски закон о држ. правној аутономији сачувају од мађ. повреда. У посљедње вријеме говорило се о српско-хрватском споразуму, али сви закључци о српско-хрватској слози на основи неких симпатичних појава из прошле године, сувише су брзи и преурањени.“ Прибићевић је сматрао да до рашчишћавања „српско-хрватског питања није дошло зато јер хрватска политика све до сада није конкретизирала своје погледе на српско питање ... Ова неодређеност, ова безбојност хрватске странке права у српском питању не може послужити као основа за братски споразум ... Хрватска опозиција колеба се још увијек између реализма младе хрв. генерације и старчевићанске догматике старијих. А ова догматика буквални је хрв. превод с оригинала мађарског. Њезина је садржина основана на држ.-правном гледишту, које је по свом извору аристократско, по својим средствима антикварнополитичко, а по својим циљевима ултра-шовинистичко. И као што мађ. држ. правна теорија утапа немађарске народе у јединствени политички народ мађарски, тако и хрв. држ. правно гледиште брише српски народ, да га упије у пол. народу хрватском. “27 Прибићевић није нападао само опозицију због њене јаловости, већ и владајућу Народну странку, као и Србе у њој, тврдећи како се у „Народној странци, неповратно изгубио Српски клуб. Они дакле немају ништа заједничко са српским захтјевима, поготову ако се уважи, да је „програм сирочета без оца“, програм Васе Ђурђевића за хрватску „народну“ странку апокрифан ... У земаљском сабору не чује се данас слободна српска ријеч. “28 Борба против владајуће странке настављала се и у његовим нападима на бана Пејачевића, због тога, што је „његов систем пуном

\footnotetext{
${ }^{24}$ Нови Србобран, 3 / 5 (18). 1 1905, 1.

${ }^{25}$ Исто, 31 / 11(24). 2 1905, 1-2.

${ }^{26}$ Исто, 249 / 13(26). 11 1904, 1.

${ }^{27}$ Исто, 33 / 13(26). 2 1904, 2.

${ }^{28}$ Исто, 17 / 24.1 (6.2) 1904, 1.
} 
паром запловио у реакционарне воде.“29 Прибићевићеви напади на бана нису јењавали, јер је он добро оценио да је политика стезања опозиције с једне стране и настојање да се испољи наклоност према Србима с друге стране, итекако смишљен потез Пејачевића и Народне странке, у циљу прдобијања Срба и тиме разбијања тешко стечене слоге између политичара хрватске и српске опозиције. Због свега тога, Прибићевић је појачавао своје напоре на обједињавању опозиције, па је тако на поузданичкој скупштини Српске самосталне странке у Петрињи, од 4. августа 1904. године, „разложио потребу опозиције и показао, да она има једнако право на живот као и владина странка. Али та опозиција мора се што прије ујединити, бити напредна и савремена.“ Осим ове потребе он истиче да је „нужно опће право гласа које има бити тајно“, затим, „слобода штампе, збора и договора.“30

А да су се хрватско-српски односи развијали у том смеру доказе смо добили већ половином 1904. године, када су почели да се ређају догађаји који су указивали да је преброђена тешка криза између Срба и Хрвата, чему су доказ биле многобројне манифестације, које су све више попримале политичке садржаје. Као круна тог отопљавања, уследила је одлука Средишњег одбора Српске самосталне странке донета 27. маја 1904. године да се ступи у изборну коалицију са Хрватском странком права $^{31}$, али до стварања коалиције требало је још причекати, јер „све до сад ова странка није нашла за потребно, да одреди своје становиште према српским захтјевима, а њезин орган ( мисли на „Обзор“ - опаска аутора) замириши понекад, као што видимо, штавише и денунцијацијом Срба.“32

Међутим, када се сазнало да ће бити расписани избори за посланике у Сабору Хрватске, почеле су озбиљне припреме самосталаца за борбу против владајуће Народне странке. Самосталци су успели да пронађу заједнички језик са Српском народном радикалном странком и да се заједно удруже са хрватским опозиционим странкама у покушају да сруше Народну странку. У децембру 1904. године напредњаци су, више не желећи да делују у оквиру Хрватске странке права, основали своју странку и отпочели жесток сукоб са противсрпском Франковом странком. Тај чин са симпатијама је дочекан од стране самосталаца, који су о томе писали: „Наши односи према Хрватима нису се у прошлој години ништа измјенили. Они су правилнији и сносљивији него прије, али то је све. О каквом споразуму са Хрватима ... не може се ни говорити. До тог ће доћи, када се међу Хрватима утврди струја која ће потпуно раскрстити са старчевићевом засуканошћу, клерикалном нетрпељивошћу и патриотизмом аустријским ... струја ... младе хрв. генерације, која се окупила у Напредној странци ....“33

С друге стране, Прибићевић је остао разочаран страначким програмом Хрватске пучке сељачке странке, коју је у децембру 1904. године основао Стјепан Радић, његов пријатељ и политички сарадник из студентских дана. У свом тумачу ХПСС-е Радић је образлагао другу тачку њеног програма која каже да су „Хрвати и

\footnotetext{
${ }^{29}$ Исто, 124 / 11(24). 6 1904, 1.

${ }^{30}$ Исто, 160 / 27.7 (9.8) 1904, 1.

${ }^{31}$ Василије Крестић, Историја Срба у Хрватској и Славонији 1848-1914, Београд 1991, 428-429.

${ }^{32}$ Нови Србобран, 177 / 17.(30) 8 1904, 1.

${ }^{33}$ Исто, 1 / 3. (16) 1 1905, 1.
} 
Срби један народ, па се већ зато морају споразумјети и у политичком раду, нарочито ондје гдје живу заједно“. Ту је он мислио „на све Хрвате и на све Србе, а не само на Хрвате и на православне у банској Хрватској. Сви православни у Банској Хрватској нису наиме пориетлом Срби, Срби су само Сриемци.“"34 Због оваквог става према Србима дошло је до његовог дугогодишњег разлаза са Прибићевићем, који је у „Новом Србобрану“ правилно оценио да се „програм сељачке странке не обазире на српско питање“ и да је „главна ствар у том, да ли Хрвати мисле водити рачуна о посебним српским тежњама, које су основане на свијести српског народа у својој посебној народној личности, на љубави српског народа према свом народном имену.“35 Међусобна оптуживања Прибићевића и Радића наставила су се и током 1905. године, а у једном од својих одговора Радићу, Прибићевић одлично анализира „Стипин заокрет“, „његово приближавање Франку, јер тврди да су у Србији Срби, а у Хрватској да нису баш Срби, али кад се они због вјере зову Србима, не треба их у томе сметати. Стипица је издао начело јединства хрватског и српског народа, којему је био склон од 1898.“36

На пролеће 1905. године самосталци су одлучили да уђу у коалицију са радикалима и „са оним хрв. опозиционим странкама које се у својим погледима на срп. питање буду руководиле тежњом за споразумом са Србима.“37 Самосталци и радикали, према Прибићевићевим речима, чинили су све „да се створе услови за изборну коалицију ... да се ступи у изборни споразум са хрватском опозиционом коалицијом, ако у њој не буде „чистих“ и „побожних“ (франковаца и фуртимаша) .... Међутим, на хрватској је страни такав хаос, да се још задуго не можемо надати чистој ситуацији.““38 И ту је Прибићевић био у праву, јер је колебљива политика хрватских политичара према Србима постала „жалостан предмет из 1903. године када се почело живље радити на зближавању Срба и Хрвата.“39 Због тога, Прибићевић је упозоравао „да се хрватско питање може ријешити само на три начина. Или у споразуму са Србима, или помоћу Пеште или помоћу Беча. Сва три правца се не могу изабрати, јер се међусобно потиру, али, који се изабере њега се ваља држати ... пошто су Беч и Пешта дволични до споразума може доћи само са Србима ... јер се хрватско питање може ријешити само заједничком српскохрватском снагом. “ $“ 40$

У исто време, на тај проблем, једнако су гледала двојица хрватских политичара из Далмације, Франо Супило и Анте Трумбић. Они су слично Прибићевићу видели прилику у кризи дуализма коју би могли да искористе у циљу уједињења Далмације са Хрватском и Славонијом. По њиховом мишљењу, криза мађарске владе као и тешки преговори које је краљ водио са мађарском опозицијом,

\footnotetext{
${ }^{34}$ А. Радић И С. Радић, Тумач к програму или што је и што хоће Хрватска пучка сељачка странка, објављено у књизи А. Радића, Сабрана дјела, Загреб 1936, 108-109.

${ }^{35}$ Исто, 79.

${ }^{36}$ Нови Србобран, 183 / 31.8 (13.9) 1905, 1.

${ }^{37}$ Исто, 105 / 16. (29.) 5 1905, 1.

${ }^{38}$ Исто, 155 / 23.7 (5.8) 1905, 1.

${ }^{39}$ Исто, 48 / 3. (16.) 3 1905, 1.

${ }^{40}$ Исто.
} 
довољни су били да се покрене питање решења најакутнијих проблема хрватских земаља. Стара тежња за окупљањем снага и Хрватске и Далмације поново се појавила, јер је мађарска либерална странка, која је на власти у Хрватској држала Куенову творевину Народну странку, доживела потпуни слом. Тако се поставило питање у коме треба тражити ослонац - да ли у Бечу или у Пешти. Супило и Трумбић су сматрали да је потребно наћи заједнички језик са Србима, Србијом, али првенствено са мађарском опозицијом. Због тога, Супило је отишао у Београд где је дошао у додир са српским службеним круговима, а Трумбић је разговарао са Ференцом Кошутом настојећи да пронађе заједнички језик са сарадњи склоним мађарским политичким круговима. Поступајући у складу са политичким деловањем двојице својих истакнутих вођа, у пролеће 1905. Године, довршио се процес повезивања између Народне хрватске странке и Странке права, оснивањем јединствене Хрватске странке која је требала да активно ради на сарадњи и стварању коалиције између српских и хрватских странака. Изван ове странке су остали „чисти“ праваши и напредњачка група око др. Јосипа Смодлаке. На оснивачкој седници у Сплиту, Хрватска странка је у свом политичком програму изјавила „да су Хрвати и Срби један народ по крви и језику, нераздруживо спојени земљиштем, на којем обитавају, те ће према тому радити да се уклоне и онемогуће размирице, а да се увриежи љубав међу њима, на основи здравог самокупног рада за обћи народни бољитак.“41 Након бројних тешкоћа далматински поборници „новог курса“ успели су да наговоре бановинске политичаре да прихвате сарадњу са мађарском опозицијом. Дана 3. октобра 1905. године састала се на Ријеци већина хрватских посланика из Хрватске и Далмације и потписала познату Ријечку резолуиију којом су подржали мађарску опозицију у њеној борби за потпуну државну самосталност - за персоналну унију. Истакли су да су хрватски и мађарски народ упућени један на други и у одбрани од спољне опасности (мисли се на немачки „продор на исток“). Ријечка резолуција је поставила као услов за хрватску помоћ мађарској опозицији уједињење хрватских земаља и увођење уставних слобода у Хрватској, односно, обарање мађаронског режима.

На посебном скупу хрватских политичара у Ријеци, после доношења резолуције, учествовали су и представници Српске самосталне странке, међу којима и Светозар Прибићевић, који је о томе рекао да је „први корак хрватског извршног одбора био тражење споразума са Србима.“"2 Позиву хрватских колега они су се одазвали због тога што им је речено „да „чисти“ нису позвани и да с њима више неће ступати ни у какву кооперацију.“43 На том састанку расправљали су о изборној сарадњи, али самосталци, због споразума са радикалима, нису хтели да воде никакве сепаратне преговоре.

Упркос тој чињеници, „Нови Србобран“ је пожурио да изрази своје одушевљење овом резолуцијом, пишући како „већ данас она представља, на хрв. страни, читав прелом у схваћању нашег положаја између Аустрије и Угарске.

\footnotetext{
${ }^{41}$ Василије Крестић, Историја Срба у Хрватској и Славонији 1848-1914, 431.

${ }^{42}$ Исто, 433.

${ }^{43}$ Исто, 432.
} 
Резолуција ... одлучно пристаје уз Пешту. Ријечка резолуција сматрајући да је мађарска борба за самосталност оправдана, стаје на исправно гледиште ... Становиште Ријечке резолуције у питању сједињења Далмације, основано је на државно-правној нагодби од 1868. године. Нема сумње, то је начин који би, за питање сједињења могао загријати и Србе. До сада су Хрвати тражили сједињење на подлози магловитог историчког државног права, које је својим обимом и својим интересом наперено против српског народа.“44

Две недеље после ових дешавања, српски посланици из Хрватске и Далмације прихватили су пружену руку својих хрватских колега, усвојивши Задарску резолуиију, у којој су такође подржали мађарску опозицију баш каошто их је подржала Ријечка резолуција. Они су били спремни да се боре за уједињење Хрватске и Далмације, али под условом да хрватске странке признају равноправност хрватског и српског народа. У припремању, формулисању и прихватању Задарске резолуције значајан допринос дао је управо Светозар Прибићевић. Он је прихватио начела Ријечке резолуције налазећи у њима упориште за остваривање сопственог политичког програма. Наиме, он је у њој видео полазиште са споразумевање до тада оштро супротстављених страна. Карактеристично је да је у Задарској резолуцији истакнуто да су Срби и Хрвати један народ, што је била већ пре исказана Прибићевићева теза. ${ }^{45}$

Непосредни резултат ових двеју резолуција био је договор Хрватске странке и Српске странке у Далмацији, на основу којег је закључена сарадња по питању борбе за сједињење Хрватске и Далмације, а напосе је истакнуто да су Хрвати и Срби један народ. Потписани хрватски и српски посланици обавезали су се да се заједнички језик службено зове хрватски или српски, да се у школама учи хрватска и српска историја, као и латиница и ћирилица, а да у далматинским општинским већима где има бар трећина српских посланика треба поред хрватске поставити и српску заставу. ${ }^{46}$

Ријечком и Задарском резолуцијом, као и поменутим договором двеју странака, коначно је довршен период приближавања хрватске и српске политике, а тиме је и створен темељ за политику „новог курса“. Али с друге стране, не може се рећи да је тиме све решено, јер „нови курс“ су нападали: мађарони, клерикалци, франковци и сељачка странка. Франковци су чак покренули „народну буру“ којој је циљ био да протестним скупштинама „одува“ политику „новог курса“. Наравно, франковцима није био циљ само слепо служење Бечу, већ су и они настојали да стекну што већу независност Хрватске, као и њено уједињење са Далмацијом, али, за разлику од резолуционаша, они су сматрали да се тај циљ може остварити само уз помоћ Беча, а никако уз помоћ Срба, према којима су показивали све отворенију мржњу.

Ријечка и Задарска резолуција постале су темељ формирања Хрватскосрпске коалиције, коју су чиниле: Хрватска странка права, Хрватска напредна

\footnotetext{
$\overline{{ }^{44} \text { Нови Србобран, } 201 / 22.9 \text { (5.10) 1905, } 1 .}$

${ }^{45}$ Хрвоје Матковић, Светозар Прибићевић идеолог, страначки вођа, емигрант, Загреб 1995, 21.

${ }^{46}$ Ј. Шидак, М. Грос, И. Караман, Д. Шепић, Повијест хрватског народа 1860-1914, Загреб 1968, 222.
} 
странка, Српска самостална странка и Српска народна радикална странка. Неко време придружила им се и Социјалдемократска странка. Нову политику нису прихватиле Чиста странка права, Народна странка и Хрватска пучка сељачка странка, која је с једне стране, пошто је тек формирана, желела да очува своју самосталност, а с друге стране, није веровала Мађарима ни кад су у опозицији и кад траже сарадњу са Хрватима.

\section{Закључак}

Са оснивањем Хрватско-српске коалиције може да се закључи да се завршио један период политичког живота Светозара Прибићевића у којем се он у целости изградио као зрела политичка личност, која је од самог почетка свог деловања одбацила државно-правне аргументе и историјске чиниоце не признавајући никаквих разлика међу јужнословенским народима. У том периоду, он је успео да самосталцима наметне нови програм који је „пристао уз гледиште о народном јединству Срба и Хрвата и захтјевао је коријените демократске реформе. Од 1906. до 1918. та је странка у Хрватском сабору заступала готово све српске изборне округе у Хрватској и била је главним ослонцем Хрватско-српске коалиције.““77 Таквим радом Прибићевић је успео да са стварањем Хрватско-српске коалиције обједини своје напоре зацртане на састанку „омладинаца“ у Максимиру из 1898. године и да повеже српске и хрватске странке на заједнички рад и сарадњу, што му је био циљ још из студентских дана.

\section{Извори и литература:}

\section{Периодика:}

Глас 1899; Застава, 1903; Нови Србобран, 1903, 1904, 1905; Србобран 1903, 1914.

\section{Литература:}

Гашић, Ранка, Србобран гласило Српске самосталне странке у Троједнищи 1903-1914, магистарски рад.

Крестић, Василије, Историја Срба у Хрватској и Славонији 1848-1914, Београд 1991.

Матковић, Хрвоје, Светозар Прибићевић идеолог, страначки вођа, емигрант, Загреб 1995.

Прибићевић, Светозар, Мисао водиља Срба и Хрвата, Београд 1940.

Прибићевић, Светозар, Диктатура краља Александра, Загреб 1990.

Радић, Антон, Сабрана дјела, Загреб 1936

Ракић, Лазар, Радикална странка у Војводини 1902-1919, Нови Сад 1983.

Ћоровић, Владимир, Портрети из новије српске историје, Београд 1990.

Шидак, J, Грос, М, Караман, И., Шепић, Д, Повијест хрватског народа 1860-1914, Загреб 1968.

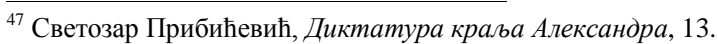




\title{
A PERIOD OF POLITICAL MATURATION OF SVETOZAR PRIBIĆEVIĆ 1875-1905
}

\begin{abstract}
Summary
With the establishment of the Croatian - Serbian coalition it could be concluded that the period of political life of Svetozar Pribicević, in which he built himself as a political figure, was crowned by the rejection of the state-legal arguments and historical factors, failing to recognize any difference among the South Slavs. During this period, he managed to impose a new program to his party, agreeing with the view of the national unity of Serbs and Croats, and demanding radical democratic reforms. From 1906 to 1918, the party in the parliament represented almost all Serbian electoral districts in Croatia, mainly relying on the Croatian-Serbian coalition. During his work on the mentioned political course, he succeeded with the creation of the Croatian-Serbian coalition in order to unite their efforts in meeting the "youths" in Maksimir in 1898, and linking the Serbian and Croatian parties to work together and cooperate, which was his goal since the college days.
\end{abstract}

Keywords: Svetozar Pribićević, Serbs, Croatia, politics, cooperation, unity 